\title{
Clostridium difficile Colitis and Neutropenic Fever Associated with Docetaxel Chemotherapy in a Patient with Advanced Extramammary Paget's Disease
}

\author{
Yumi Nonomura Atsushi Otsuka Yuichiro Endo Akihiro Fujisawa \\ Miki Tanioka Kenji Kabashima Yoshiki Miyachi \\ Department of Dermatology, Kyoto University Graduate School of Medicine, Kyoto, Japan
}

\section{Key Words}

Clostridium difficile colitis - Neutropenic fever - Extramammary Paget's disease · Docetaxel

\begin{abstract}
Extramammary Paget's disease is a rare cutaneous malignant neoplasm. Previous studies indicated the efficacy of docetaxel in advanced cases. The common side effects of docetaxel are usually tolerable and seldom life-threatening. We experienced a case of severe pseudomembranous colitis and neutropenic fever that developed just after the first cycle of docetaxel chemotherapy. To the best of our knowledge, there are few reports of pseudomembranous colitis associated with docetaxel administration for skin cancers. The patient showed complete resolution of her symptoms within 2 weeks with an oral metronidazole therapy. During the second and third cycles, the patient received docetaxel safely with lower doses. The present case indicated that pseudomembranous colitis should be included in the differential diagnosis when assessing patients who develop severe diarrhea during systemic chemotherapy with docetaxel.
\end{abstract}

\section{Introduction}

Extramammary Paget's disease (EMPD) is a rare cutaneous malignant neoplasm that arises in areas in the apocrine glands. Although EMPD is usually a non-invasive intraepithelial adenocarcinoma, some cases of EMPD infiltrate the dermis and show lymph node or distant metastases. Previous studies have shown cases of advanced EMPD successfully treated with docetaxel [1]. Common side effects of docetaxel are 
usually tolerable and seldom life-threatening. We experienced a case of severe Clostridium difficile colitis and neutropenic fever that developed just after the first docetaxel chemotherapy for EMPD. To the best of our knowledge, there are few reports of $C$. difficile colitis associated with docetaxel use for skin cancer.

\section{Case Report}

A 67 -year-old Japanese female with stage IV EMPD of the vulva was treated with $75 \mathrm{mg} / \mathrm{m}^{2}$ docetaxel for the first time. Two weeks before docetaxel administration, oral cefcapene had been administered for 3 days at another clinic to prevent infection after biopsy of the vulva. On day 4 of the first cycle therapy, she developed severe watery diarrhea that quickly became bloody. On day 6 , she was immediately admitted to the hospital. Physical and other examinations revealed grade 3 neutropenic fever and diarrhea (Common Terminology Criteria for Adverse Events version 4.0) more than 10 times per day, with slight abdominal pain but no nausea or vomiting. She was treated with an injection of granulocyte colony-stimulating factor and piperacillin/tazobactam. Stool enzyme immunoassays for $C$. difficile toxins were positive. C. difficile colitis was diagnosed, and therefore an additional antibiotic therapy with oral metronidazole and antibiotic-resistant lactic acid bacteria drug was initiated. The patient had complete resolution of her symptoms within 2 weeks. One month after the administration of docetaxel, we found that the tumor had remarkably decreased in size and the serum tumor marker test showed a considerably decreased level of carcinoembryonic antigen (from $158 \mathrm{ng} / \mathrm{ml}$ before to $13 \mathrm{ng} / \mathrm{ml}$ after chemotherapy). Therefore, we decided to pursue docetaxel treatment with a decreased dose of $37.5 \mathrm{mg} / \mathrm{m}^{2}$ after informed consent was obtained. During the second and third cycle, no apparent side effects other than neutropenia without fever were observed. The tumor continued to decrease in size, and the serum carcinoembryonic antigen level was $5 \mathrm{ng} / \mathrm{ml}$ after the third cycle of chemotherapy.

\section{Discussion}

C. difficile colitis is a well-known complication of antibiotic treatment that can also be observed, albeit rarely, with certain chemotherapeutic agents [2]. Some chemotherapeutic agents are also associated with different grades of inflammation and necrosis of the colonic mucosa with alteration of the intestinal flora [2]. This has been proposed as the pathophysiological mechanism responsible for the development of C. difficile colitis in some patients receiving these drugs [2]. Methotrexate has been the most commonly implicated agent of this class but platinum-containing drugs and taxanes are well-known for their potential to cause extensive inflammatory changes in the colonic mucosa, therefore creating a favorable environment for the overgrowth of C. difficile and production of its exotoxins [2]. Including the present case, there are 5 cases of $C$. difficile colitis or pseudomembranous colitis related to docetaxel use (table 1) $[2,3]$. The patients developed colitis within 4 to 10 days after docetaxel administration, and 3 of the 5 patients developed neutropenia at the same time. The immunosuppressive condition due to neutropenia and inflammatory changes in the colonic mucosa caused by docetaxel might contribute to the development of severe C. difficile colitis. The cases indicated that $C$. difficile colitis should be included in the differential diagnosis when assessing patients who develop severe diarrhea during systemic chemotherapy with docetaxel. Including the present case, only 2 cases had positive stool assays for $C$. difficile toxin. Negative stool assays for $C$. difficile toxins should not lead the clinician away from this diagnosis if there is a strong suspicion of this disease. Colonoscopy or sigmoidoscopy are useful diagnostic procedures as the presence of pseudomembranes in the colon is pathognomonic of $C$. difficile-associated 
disease. The present case also indicated the possibility that docetaxel treatment can be continued with lower doses even after the patient developed $C$. difficile colitis associated with docetaxel chemotherapy.

\section{Disclosure Statement}

None of the authors have a conflict of interest to declare.

Table 1. Review of the 5 cases of $C$. difficile colitis or pseudomembranous colitis associated with docetaxel use

\begin{tabular}{|c|c|c|c|c|c|}
\hline & Case 1 & Case 2 & Case 3 & Case 4 & $\begin{array}{l}\text { Case } 5 \\
\text { (present case) }\end{array}$ \\
\hline Age/sex, years & $83 /$ male & $47 /$ male & 41/female & 45/female & $67 /$ female \\
\hline Diagnosis & $\begin{array}{l}\text { adenocarcinoma of } \\
\text { the pancreas }\end{array}$ & $\begin{array}{l}\text { adenocarcinoma of } \\
\text { the lung }\end{array}$ & $\begin{array}{l}\text { invasive ductal } \\
\text { carcinoma of the breast }\end{array}$ & breast cancer & $\begin{array}{l}\text { extramammary } \\
\text { Paget's disease }\end{array}$ \\
\hline $\begin{array}{l}\text { Chemotherapy } \\
\text { (21-day cycles } \\
\text { for all) }\end{array}$ & $\begin{array}{l}\text { day } 1 \text { and } 8: \\
\text { docetaxel } 30 \mathrm{mg} / \mathrm{m}^{2} \\
\text { days 1-14: } \\
\text { capecitabine 1,600 } \\
\mathrm{mg} / \mathrm{m}^{2}\end{array}$ & $\begin{array}{l}\text { day 1: } \\
\text { docetaxel } 70 \mathrm{mg} / \mathrm{m}^{2} \\
\text { and carboplatin AUC } 6\end{array}$ & $\begin{array}{l}\text { day 1: } \\
\text { docetaxel } 70 \mathrm{mg} / \mathrm{m}^{2} \text { and } \\
\text { cisplatin } 70 \mathrm{mg} / \mathrm{m}^{2}\end{array}$ & $\begin{array}{l}\text { day 1: } \\
\text { docetaxel } 75 \mathrm{mg} / \mathrm{m}^{2} \\
\text { and doxorubicin } 50 \\
\mathrm{mg} / \mathrm{m}^{2}\end{array}$ & $\begin{array}{l}\text { day 1: } \\
\text { docetaxel } 75 \mathrm{mg} / \mathrm{m}^{2}\end{array}$ \\
\hline $\begin{array}{l}\text { Clinical } \\
\text { presentation }\end{array}$ & $\begin{array}{l}\text { severe bloody } \\
\text { diarrhea and } \\
\text { dehydration on } \\
\text { cycle } 1 \text { day } 8\end{array}$ & $\begin{array}{l}\text { severe bloody } \\
\text { diarrhea, febrile } \\
\text { neutropenia and } \\
\text { diffuse abdominal } \\
\text { pain on cycle } 3 \\
\text { day } 10\end{array}$ & $\begin{array}{l}\text { severe diarrhea positive } \\
\text { for occult blood, } \\
\text { abdominal pain } \\
\text { and leukocytosis on } \\
\text { cycle } 2 \text { day } 9\end{array}$ & $\begin{array}{l}\text { severe watery } \\
\text { diarrhea, vomitting, } \\
\text { abdominal pain and } \\
\text { neutropenic fever on } \\
\text { cycle } 1 \text { day } 6 \text { and } \\
\text { cycle } 2 \text { day } 4\end{array}$ & $\begin{array}{l}\text { severe diarrhea } \\
\text { positive for occult } \\
\text { blood, abdominal } \\
\text { pain and } \\
\text { leukocytosis on } \\
\text { cycle } 1 \text { day } 4\end{array}$ \\
\hline $\begin{array}{l}\text { Antibiotic } \\
\text { exposure }\end{array}$ & no & no & no & unknown & $\begin{array}{l}\text { cefcapene } 1 \text { week } \\
\text { before }\end{array}$ \\
\hline $\begin{array}{l}\text { C. difficile } \\
\text { toxin }\end{array}$ & $\begin{array}{l}\text { negative } \\
\text { (3 samples) }\end{array}$ & $\begin{array}{l}\text { positive } \\
\text { ( } 2 \text { of } 3 \text { samples) }\end{array}$ & $\begin{array}{l}\text { negative } \\
\text { (3 samples) }\end{array}$ & negative & $\begin{array}{l}\text { positive } \\
\text { (1 sample) }\end{array}$ \\
\hline $\begin{array}{l}\text { Endoscopic } \\
\text { findings }\end{array}$ & $\begin{array}{l}\text { pseudomembranes in } \\
\text { the rectum, sigmoid } \\
\text { and descending colon }\end{array}$ & $\begin{array}{l}\text { pseudomembranes in } \\
\text { the sigmoid and } \\
\text { descending colon }\end{array}$ & $\begin{array}{l}\text { moderate to severe } \\
\text { mucosal inflammation } \\
\text { of the sigmoid and the } \\
\text { rectum with diffuse } \\
\text { subepithelial } \\
\text { hemorrhages }\end{array}$ & $\begin{array}{l}\text { moderate inflamed } \\
\text { rectal mucosa } \\
\text { covered with } \\
\text { pseudomembranes }\end{array}$ & not performed \\
\hline Treatment & oral vancomycin & $\begin{array}{l}\text { IV metronidazole and } \\
\text { oral vancomycin }\end{array}$ & oral metronidazole & $\begin{array}{l}\text { metronidazole and } \\
\text { oral vancomycin }\end{array}$ & oral metronidazole \\
\hline Outcome & symptoms resolved & symptoms resolved & symptoms resolved & symptoms resolved & symptoms resolved \\
\hline
\end{tabular}




\section{References}

1 Nakamori R, Omoto Y, Yamanaka K, Habe K, Kurokawa I, Mizutani H: Complete remission of advanced extramammary Paget's disease treated with docetaxel: a case report. Clin Exp Dermatol 2012;37: 194-195.

2 Carrion AF, Hosein PJ, Cooper EM, Lopes G, Pelaez L, Rocha-Lima CM: Severe colitis associated with docetaxel use: a report of four cases. World J Gastrointest Oncol 2010;2:390-394.

-3 Sundar S, Chan SY: Cholestatic jaundice and pseudomembranous colitis following combination therapy with doxorubicin and docetaxel. Anticancer Drugs 2003;14:327-329. 